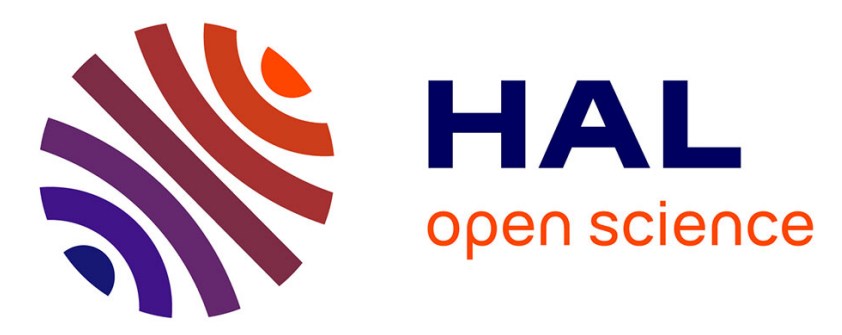

\title{
Binding properties of mono- and dimeric pyridine dicarboxamide ligands to human telomeric higher-order G-quadruplex structures
}

C. Saintomé, Patrizia Alberti, N. Guinot, P. Lejault, J. Chatain, P. Mailliet, Jean-Francois Riou, A. Bugaut

\section{To cite this version:}

C. Saintomé, Patrizia Alberti, N. Guinot, P. Lejault, J. Chatain, et al.. Binding properties of monoand dimeric pyridine dicarboxamide ligands to human telomeric higher-order G-quadruplex structures. Chemical Communications, 2018, 54 (15), pp.1897-1900. 10.1039/c7cc07048a . mnhn-02308805

\section{HAL Id: mnhn-02308805}

\section{https://hal-mnhn.archives-ouvertes.fr/mnhn-02308805}

Submitted on 8 Oct 2019

HAL is a multi-disciplinary open access archive for the deposit and dissemination of scientific research documents, whether they are published or not. The documents may come from teaching and research institutions in France or abroad, or from public or private research centers.
L'archive ouverte pluridisciplinaire HAL, est destinée au dépôt et à la diffusion de documents scientifiques de niveau recherche, publiés ou non, émanant des établissements d'enseignement et de recherche français ou étrangers, des laboratoires publics ou privés. 
Chem. Commun., 2018, 54, 1897

Received 8th September 2017, Accepted 26th January 2018

$\mathrm{DOI}: 10.1039 / \mathrm{c} 7 \mathrm{cc} 07048 \mathrm{a}$

\section{Binding properties of mono- and dimeric pyridine dicarboxamide ligands to human telomeric higher- order G-quadruplex structures†}

\author{
C. Saintome, $\ddagger^{\mathrm{ab}}$ P. Alberti, $\ddagger^{\mathrm{a}}$ N. Guinot, ${ }^{\mathrm{a}}$ P. Lejault, ${ }^{\mathrm{a}}$ J. Chatain, ${ }^{\mathrm{a}}$ P. Mailliet, ${ }^{\mathrm{a}}$ J .- \\ F. Riou ${ }^{a}$ and A. Bugaut ${ }^{a}$
}

Here, we report on the in vitro binding properties of the known pyridine dicarboxamide G-quadruplex ligand 360A and a new dimeric analogue (360A) $)_{2 A}$ to human telomeric DNA higher-order G-quadruplex (G4) structures. This study points to original binding features never reported for G4 ligands, and reveals a greater efficiency for the dimeric ligand to displace RPA (a SSDNA binding protein involved in telomere replication) from telomeric DNA.

In normal human somatic cells, telomeric DNA typically spans a 4-15 kb double-stranded region composed of 50-TTAGGG-3\% $3^{0}$ AATCCC- $5^{0}$ tandem repeats that ends with an about 150-300 nt single-stranded $3^{0}$-overhang. ${ }^{1}$ The G-rich strand of telomeric DNA is prone to fold into G4 structures, which have been visualised in human cells using a structure-specific antibody. ${ }^{2}$ Over the past two decades, a large number of small molecules have been synthesized and tested for their potential to interact with human telomeric G4 structures. ${ }^{3}$ Some of these G4 ligands have been reported as telomere-targeting agents able to interfere with the binding of telomere-associated proteins. $^{4}$

So far, most of the studies on the interactions between human telomeric DNA and G4 ligands have focused on short sequences able to fold into a single G4 unit. However, others and we have shown that longer telomeric DNA sequences can form higher-order structures consisting of several contiguous G4 units joined by TTA linkers. ${ }^{5,6}$ A few recent studies have indicated that the binding properties of a ligand to multimeric G4 structures can significantly differ from its binding to a single G4 unit. $^{7}$

Pyridine dicarboxamide derivatives are synthetic organic molecules that are amongst the most potent and selective G4 ligands. A lead molecule from this family is 360A (Fig. 1A),

\footnotetext{
a "Structure and Instability of Genomes" laboratory, Sorbonne Universités, Muséum National d'Histoire Naturelle (MNHN), Inserm U1154, CNRS UMR 7196, 75005 Paris, France.E-mail: abugaut@mnhn.fr

${ }^{b}$ UPMC Paris 6 Université, 75005 Paris, France

$\ddagger$ These authors contributed equally to the work.
}

which we previously developed and was the first molecule of this family to be evaluated for its G4 binding properties. ${ }^{8}$ This molecule was shown to display a good selectivity for G4 structures as compared with double-stranded DNA, and it was demonstrated that $360 \mathrm{~A}$ preferentially localises at telomeres in human living cells. ${ }^{9}$ The use of dimeric G4 ligands, composed

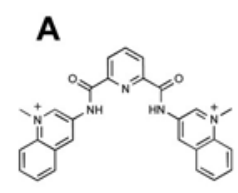

$360 \mathrm{~A}$

$\mathrm{B}_{40}$

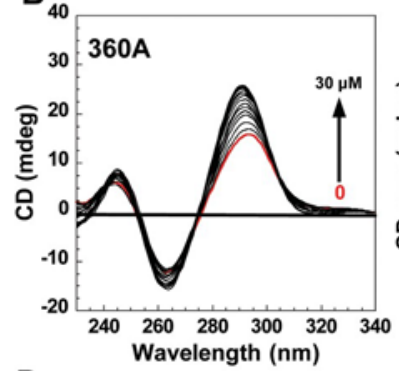

D

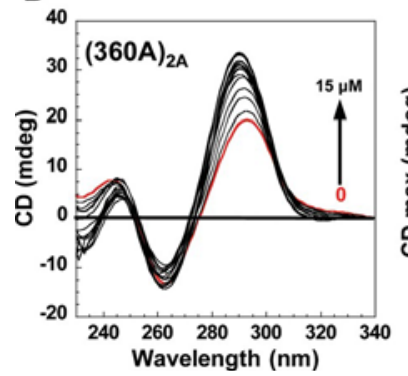

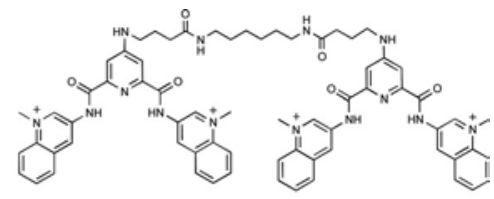

$(360 A)_{2 A}$

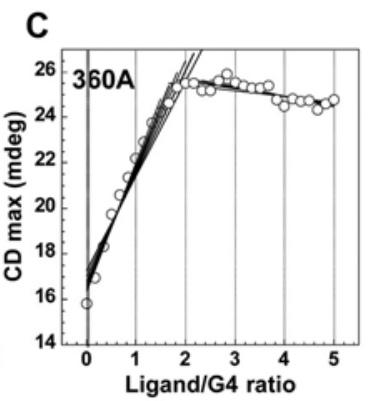

E

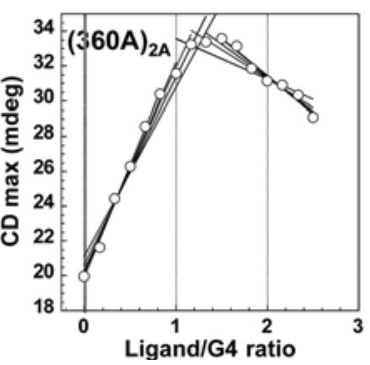

Fig. 1 (A) Chemical structures of the G4 ligands used in this study. Counter ions are $\mathrm{I}^{-}$. ( $\mathrm{B}$ and $\mathrm{D}$ ) Changes in the $\mathrm{CD}$ spectrum and $(\mathrm{C}$ and $\mathrm{E})$ changes in the maximum CD value of $\mathrm{H} 21(6 \mathrm{mM}$ in $10 \mathrm{mM}$ lithium cacodylate $\mathrm{pH} 7.2,100 \mathrm{mM} \mathrm{NaCl}$ ) upon addition of increasing amounts of $360 \mathrm{~A}$ and $(360 \mathrm{~A})_{2 \mathrm{~A}}$. 
of two G4 ligand moieties linked together by a chemical arm, has been proposed as a possible means to enforce the targeting of contiguous telomeric G4s. ${ }^{10}$ In this work, we have synthesized a dimer of 360A (see Materials and methods in ESI $\dagger$ ), named $(360 \mathrm{~A})_{2 \mathrm{~A}}$ (Fig. 1A); and we have characterized the binding of $360 \mathrm{~A}$ and its newly synthesized dimeric form $(360 \mathrm{~A})_{2 \mathrm{~A}}$ to human telomere-mimicking oligonucleotides forming an increasing number of contiguous G4 units.

In order to assess the stabilization and selectivity of $(360 \mathrm{~A})_{2 \mathrm{~A}}$ towards human telomeric G4s, we performed competitive FRETmelting experiments in the presence of a large excess of unlabelled double-stranded DNA (ds26, Table S1, ESI $\dagger$ ). We used either a fluorescent-labelled 21 nt oligonucleotide (F21T), which forms a single telomeric G4 structure, or three oligonucleotides (H69Q1, H69Q2 and H69Q3) that form fluorescentlabelled contiguous G4s (see Materials and methods in ESI†). The results demonstrated that the dimer ligand is a strong stabilizer of telomeric G4s and exhibits a great G4 vs. duplex selectivity (Fig. S1, ESI $\dagger$ ).

Next, we used CD spectroscopy to evaluate the binding stoichiometry. ${ }^{11}$ We first carried out CD titration experiments using $\mathrm{H} 21$ oligonucleotide that folds into a single G4 unit (Table S1, ESI $\dagger$ ). We titrated a $6 \mathrm{mM}$ solution of $\mathrm{H} 21$ in a sodium containing buffer with increasing amounts of 360A or its dimer analogue $(360 \mathrm{~A})_{2 \mathrm{~A}}$. The changes in the CD spectrum of H21 upon increasing the concentration of $360 \mathrm{~A}$ ligand up to $30 \mathrm{mM}$ by increments of $1 \mathrm{mM}$ are shown in Fig. 1B. In the absence of ligand, the CD spectrum of $\mathrm{H} 21$ displayed the characteristic signature of an antiparallel G-quadruplex structure, with a major positive band around $295 \mathrm{~nm}$ and a negative band at about $265 \mathrm{~nm}$. Addition of 360A led to an increase in the $295 \mathrm{~nm}$ band up to about a $12 \mathrm{mM}$ ligand concentration in solution, at which a maximum amplitude was reached. The spectral changes occurred immediately after each addition, and did not progress over time. This result indicated a 2 : 1 molar ratio of $360 \mathrm{~A}$ to $\mathrm{H} 21$, presumably involving interactions with the two terminal G-quartets of the G4 structure. Stoichiometry values and associated errors were also determined by multiple linear regression analyses (Fig. 1C and Table S2, ESI $\dagger$ ), with systematically varying the range of fitting. Titration of a $6 \mathrm{mM}$ solution of $\mathrm{H} 21$ with $(360 \mathrm{~A})_{2 \mathrm{~A}}$ showed again an increase of the positive band around $295 \mathrm{~nm}$ (Fig. 1D); however, a maximum value was reached at around $7 \mathrm{mM}$ ligand concentration, indicating a 1 : 1 binding stoichiometry of $(360 \mathrm{~A})_{2 \mathrm{~A}}$ to H21 (Fig. 1E). $\S$ This suggests that the chemical arm between the two aromatic G4-binding moieties is long enough to afford them interacting with the top and the bottom G-quartet surfaces of the G4 structure in a "sandwich-like" manner. Such result is comparable to other studies from the Nagasawa's laboratory on dimers of macrocyclic hexaoxazole ligands. ${ }^{12}$

We then investigated the binding stoichiometry of 360A and $(360 \mathrm{~A})_{2 \mathrm{~A}}$ to telomeric oligonucleotides able to form two and three contiguous intramolecular G4 structures, named H45 and H69, respectively (Table S1, ESI $\dagger$ ). ${ }^{6}$ In these experiments, DNA strand concentrations were adjusted in order to maintain an identical G4 unit concentration (6 mM) in solution.

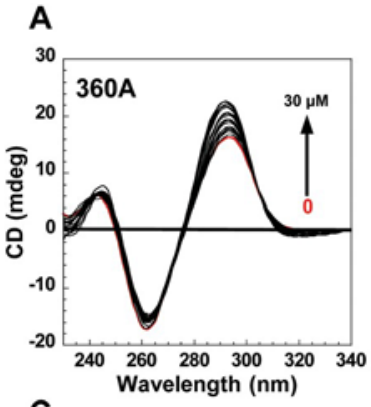

B
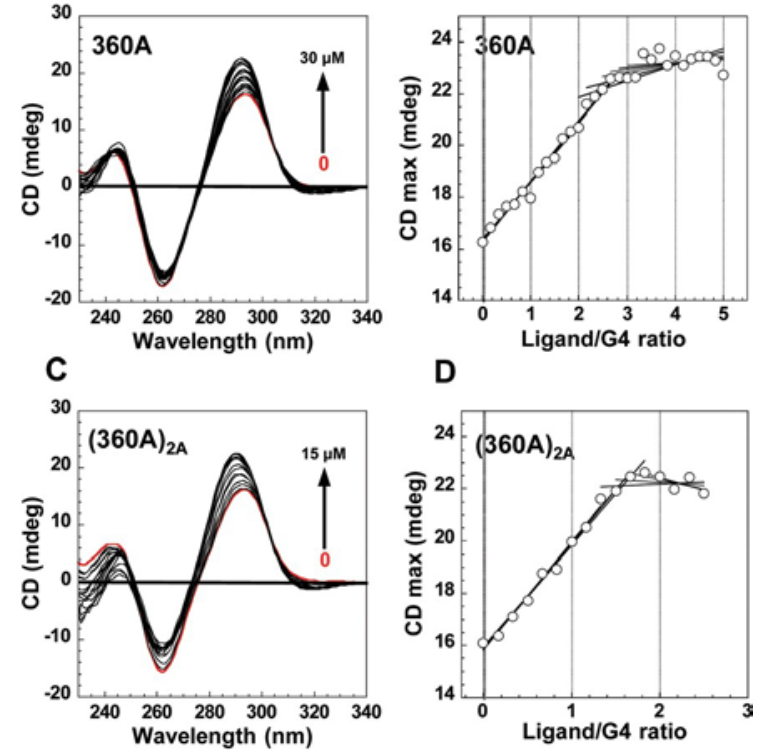

D

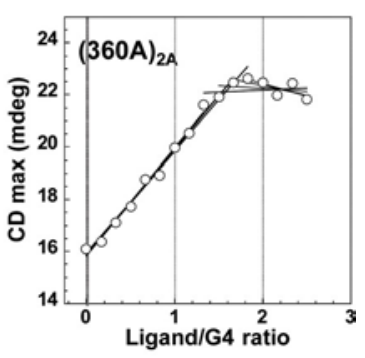

Fig. 2 ( $A$ and $C$ ) Changes in the CD spectrum and ( $B$ and $D$ ) changes in the maximum $\mathrm{CD}$ value of $\mathrm{H} 69$ ( $2 \mathrm{mM}$ in $10 \mathrm{mM}$ lithium cacodylate $\mathrm{pH} 7.2$, $100 \mathrm{mM} \mathrm{NaCl}$ ) upon addition of increasing amounts of $360 \mathrm{~A}$ and $(360 \mathrm{~A})_{2 \mathrm{~A}}$.

Consequently, in the absence of ligand, the CD spectra of H45 and H69 have similar shapes and amplitudes (Fig. 2 and Fig. S3, ESI $\dagger$ ). ${ }^{6}$ As for H21, we also observed an increase in the positive CD signal around $295 \mathrm{~nm}$ upon increasing the concentration of ligand in solution, until it reached a maximum value (Fig. 2 and Fig. S3, ESI†). However, from these experiments, we determined ligand to G4 unit molar ratios higher than the one obtained for H21 (see Table S2, ESI $\dagger$ ). For 360A, the determined binding stoichiometry was around 2.5 with $\mathrm{H} 45$ (Fig. S3A and B, ESI†), and 2.7 with H69 (Fig. 2A and B); while for $(360 \mathrm{~A})_{2 \mathrm{~A}}$, it was around 1.5 and 1.7 for $\mathrm{H} 45$ and H69, respectively (Fig. 2C, D and Fig. S3C, D, ESI†).

These binding stoichiometries that exceeded what could be conceived by taking into account the results obtained with H21 suggested that new binding sites became available when telomeric G4 units are arranged contiguously. Noteworthily, the obtained binding stoichiometries seemed to increase with the length of the oligonucleotide used, matching with the number of TTA linkers anchoring the G4 units together. If a TTA linker gives rise to one extra binding site for the ligands, the calculated 360A : G4 unit molar ratios would be of 2.50 for H45 and of 2.67 for H69 (Table S2, ESI †). These calculated values are very close to our experimental values (Fig. 3 and Table S2, ESI†). This has also been verified for H93, an oligonucleotide capable of forming four contiguous G4 units (Fig. 3 and Tables S1, S2, ESI $\dagger$ ). For the dimeric ligand $(360 \mathrm{~A})_{2 \mathrm{~A}}$, the experimental ligand : G4 ratio values also followed the trend of the calculated values (Fig. 3 and Table S2, ESI $\dagger$ ). These results indicate that, for both $360 \mathrm{~A}$ and $(360 \mathrm{~A})_{2 \mathrm{~A}}$, a binding site exists between two adjacent G4 units in a multimeric telomeric G4 structure.

To further investigate this possibility, we next wondered whether the observed stoichiometry values depended on the 


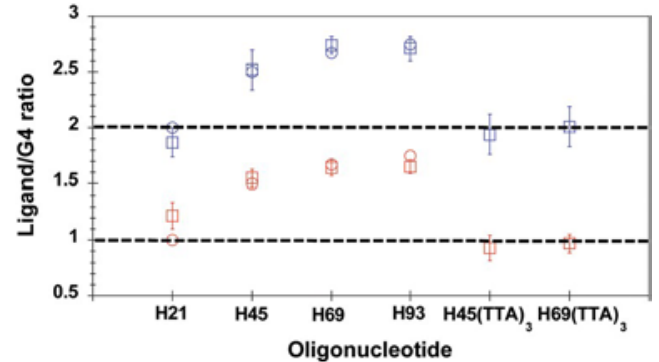

Fig. 3 Calculated (open circle) versus experimental (open square) ligand to $\mathrm{G} 4$ ratio values (Table $\mathrm{S} 2$, ESI $\dagger$ ) for the telomeric oligonucleotides $\mathrm{H} 21$, $\mathrm{H} 45, \mathrm{H} 69$ and $\mathrm{H} 93$ (see Fig. S4 in $\mathrm{ESI} \dagger$ ) and the extended oligonucleotides $\mathrm{H} 45(\text { TTA })_{3}$ and $\mathrm{H} 69(\text { TTA })_{3}$. Data for $360 \mathrm{~A}$ and $(360 \mathrm{~A})_{2 \mathrm{~A}}$ are in blue and red, respectively.

length of the TTA nucleotidic linker that joins the G4 units. We performed CD titrations with oligonucleotides bearing longer TTA linkers between the G4 units (H45(TTA) $)_{3}$ and H69(TTA) , $_{3}$ Table S1, ESI $\dagger$ ). From these experiments, we determined a binding stoichiometry of $2: 1$ for $360 \mathrm{~A}$ and $1: 1$ for its dimeric analogue $(360 \mathrm{~A})_{2 \mathrm{~A}}$ for both H45(TTA) $)_{3}$ and H69(TTA) $)_{3}$ oligonucleotides (Fig. 3 and Fig. S5, ESI†). These values are similar to the ones obtained for the single G4-forming sequence H21, indicating that the extra interstitial binding sites within the multimeric G4 structures are lost when the G4 units are moved away by additional TTA sequences.

Overall, our results point to a binding model whereby two aromatic G4-binding moieties interact with the external G-quartets of a G4 unit and a third one is accommodated in a binding pocket involving the TTA linker between two contiguous G4s. On the basis of molecular modelling simulations, Haider et al. proposed the existence of possible binding sites at the interface between two adjacent telomeric G4 units. ${ }^{13}$ Subsequently, few G4 ligands have been studied experimentally for their binding to multimeric G4 structures. ${ }^{7}$ Among them, a chiral cyclic helicene has been proposed to bind in the cleft pocket located between two adjacent human telomeric G4s. ${ }^{7 b}$ Cummaro et al. reported a spectroscopic study on the binding of a triazatruxene molecule to a telomeric higher-order structure formed by two G4 units, which revealed that two molecules could bind by end-stacking at the $5^{0}$ and $3^{0}$ extremities of the structure and a third molecule at the interface between the G4s. ${ }^{7 c}$ Bai et al. also proposed a similar binding mode for sanguinarine to a twotandem G4-forming sequence. ${ }^{7 a}$ Recently, a triaryl-substituted imidazole derivative was also found to selectively bind to telomeric G4 multimers likely through intercalating into the pocket formed between two G4 units. ${ }^{7 j}$ By contrast no intersitial binding sites between adjacent G4s were observed for a macrocyclic hexaoxazole ligand. ${ }^{7 f}$ Regarding the binding of ligand dimers to higher-order G4 structures, there has been only very few studies. $^{10}$ All these studies were carried on telomeric sequences forming two contiguous G4 structures, and no interstitial binding site was observed. Thus, when compared to previous works, our results indicate unprecedented modes of binding to multimeric G4 structures for $360 \mathrm{~A}$ and its dimeric analogue $(360 \mathrm{~A})_{2 \mathrm{~A}}$, which combine end-stacking with both external G-quartets of the G4 units and additional binding sites between the G4s. Detailed information on how these extra binding sites occur, and whether they pre-exist or are generated upon binding of the ligands to the G-quartets will require indepth structural studies.

We next sought to assess the potential of our G4 ligands to interfere with the binding of human replication protein A (RPA) to telomeric DNA. RPA is a single-stranded DNA (ssDNA) binding protein that is essential to whole genome replication, including telomeres. ${ }^{14}$ We previously showed that the efficiency of RPA binding to G4-forming telomeric sequences displays an inverse relationship with the stability of the formed structure, and that G4 ligands can impair RPA binding to single telomeric G4-forming sequences. ${ }^{15}$ We carried out gel shift experiments with RPA and the telomere-mimicking oligonucleotides used in this study. For these experiments, RPA concentration in the reaction mixture was set to obtain about 95-100\% DNA bound to RPA for all the sequences used. First, we incubated the G4 ligand and the radiolabelled DNA substrate for $5 \mathrm{~min}$, and then we added RPA to the reaction mixture and incubated for further 20 min. We observed a concentration-dependent inhibitory effect of the ligands for the association between RPA and the DNA substrates (Fig. 4A and Fig. S6A, ESI†). The ability of the ligands to inhibit RPA binding was maintained even in the presence of a large excess of the double-stranded competitor ds26 (Fig. S7, ESI†). The level of RPA/DNA complexes formed was inhibited by about 75\%, 85\% and 65\% for H21, H45 and H69, respectively, in the presence of $2.5 \mathrm{mM}$ of $360 \mathrm{~A}$. Raising the concentration of ligand to $5 \mathrm{mM}$ resulted only in a slight

A

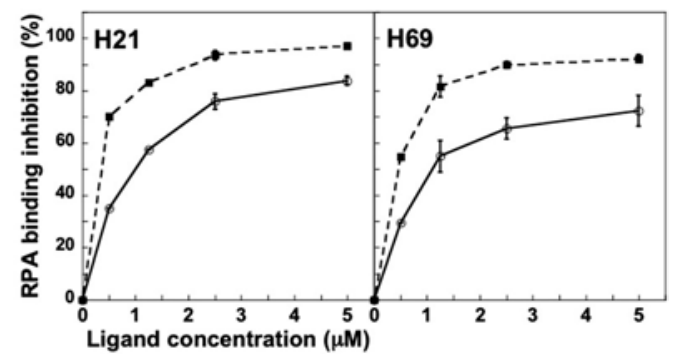

B

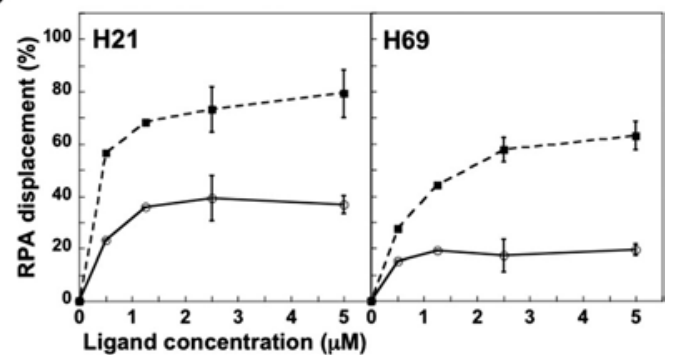

Fig. 4 (A) Percentage of inhibition of RPA binding to telomeric oligonucleotide substrates $\mathrm{H} 21$ and $\mathrm{H} 69$ in the presence of increasing concentrations of $360 \mathrm{~A}$ (open circles) or $(360 \mathrm{~A})_{2 \mathrm{~A}}$ (black squares) (B) percentage of displacement of RPA from the telomeric oligonucleotide substrates $\mathrm{H} 21$ and $\mathrm{H} 69$ (20 min incubation) upon addition of increasing amounts of $360 \mathrm{~A}$ (open circles) or (360A) $2 \mathrm{~A}$ (black squares). 
increase in RPA binding inhibition by about 5\% for all binding substrates. The dimer $(360 \mathrm{~A})_{2 \mathrm{~A}}$ exhibited a greater inhibitory effect on RPA binding to the telomeric sequences, reaching about 95\% inhibition for all binding substrates at $2.5 \mathrm{mM}$ ligand concentration in solution (Fig. 4A). By contrast, we did not observe such inhibition of RPA binding to control oligonucleotides that do not fold into G4s (Table S1 and Fig. S8, $\mathrm{ESI} \dagger$ ). These results suggested that more stable small mole-

cule/DNA complexes are formed between the dimeric ligand and the higher-order G4 structures than with the monomeric ligand. This was further corroborated by UV-melting experiments that showed higher thermal stabilities of the complexes formed with $(360 \mathrm{~A})_{2 \mathrm{~A}}$ as compared with $360 \mathrm{~A}$ for an identical aromatic core to G4 unit ratio (Table S3, ESI†).

In the nucleus of a cell, RPA may already be associated with telomeric DNA. We then asked whether our ligands were able to displace RPA from telomeric DNA. We hence performed experiments where the DNA binding substrates were pre-coated with RPA (20 min incubation) before the addition of the G4 ligand in the mixture for $5 \mathrm{~min}$ incubation. We observed that, under these experimental conditions, both G4 ligands were able to displace RPA from the DNA substrates in a concentrationdependent manner (Fig. 4B). We also performed control experiments, in the presence of a large excess of double-stranded competitor or with mutated telomeric oligonucleotide substrates, demonstrating the G4 selectivity of the ligands (Fig. S7 and S8, ESI†). Importantly, the dimer $(360 \mathrm{~A})_{2 \mathrm{~A}}$ displayed a greater efficiency in displacing RPA from telomeric DNA. When considering the longer sequence H69, $5 \mathrm{mM}$ of $(360 \mathrm{~A})_{2 \mathrm{~A}}$ dissociated about $60 \%$ of the RPA/DNA complex, while at the same concentration the $360 \mathrm{~A}$ molecule dissociated only $20 \%$ of the complex. It is noteworthy than even for the same concentration in G4-binding aromatic moiety (i.e. $2.5 \mathrm{mM}$ in $(360 \mathrm{~A})_{2 \mathrm{~A}}$ versus $5 \mathrm{mM}$ in $360 \mathrm{~A}$ ), the dimer molecule was more efficient in displacing RPA than the monomer (Fig. 4B).

In conclusion, we undertook here to evaluate the binding properties of a known G4 ligand and its new dimeric analogue towards human telomeric higher-order G4 structures. Our results propose original binding modes for these ligands, which have never been reported before with other ligands. Furthermore, we showed that the dimeric ligand is more efficient than the monomer for impairing the formation and for inducing the dissociation of the complex formed RPA and human telomeric DNA, thus highlighting the potential of dimeric G4 ligands to efficiently interfere with protein binding at telomeres in order to interrogate telomere biology.

This work was supported by Inserm, CNRS and the MNHN. P. L. was supported by a doctoral fellowship from the MNHN.

\section{Conflicts ofinterest}

There are no conflicts to declare.

\section{Notes and references}

$\S$ The choice of a sodium buffer was privileged because of the less polymorphic nature of the telomeric G4 structure in this condition, similar results were obtained in a potassium-containing buffer (Fig. S2, ESI†).

1 (a) R. K. Moyzis, J. M. Buckingham, L. S. Cram, M. Dani, L. L. Deaven, M. D. Jones, J. Meyne, R. L. Ratliff and J. R. Wu, Proc. Natl. Acad. Sci. U. S. A., 1988, 85, 6622-6626; (b) R. McElligott and

2 R. J. Wellinger, EMBO J., 1997, 16, 3705-3714. G. Biffi, D. Tannahill, J. McCafferty and S. Balasub ramanian, Nat. Chem., 2013, 5, 182-186.

3 (a) D. Monchaud and M. P. Teulade-Fichou, Org. Biomol. Chem., 2008, 6, 627-636; (b) S. Neidle, FEBS J., 2010, 277, 1118-1125.

4 (a) D. Gomez, M. F. O’Donohue, T. Wenner, C. Douarre, J. Macadre, P. Koebel, M. J. Giraud-Panis, H. Kaplan, A. Kolkes, K. Shin-ya and J. F. Riou, Cancer Res., 2006, 66, 6908-6912; (b) R. Rodriguez, S. Muller, J. A. Yeoman, C. Trentesaux, J. F. Riou and S. Balasubramanian, J. Am. Chem. Soc., 2008, 130, 15758-15759; (c) H. Tahara, K. Shin-Ya, H. Seimiya, H. Yamada, T. Tsuruo and T. Ide, Oncogene, 2006, 25, 1955-1966.

5 (a) H. Q. Yu, D. Miyoshi and N. Sugimoto, J. Am. Chem. Soc., 2006, 128, 15461-15468; (b) Y. Xu, T. Ishizuka, K. Kurabayashi and M. Komiyama, Angew. Chem., Int. Ed., 2009, 48, 7833-7836; (c) L. Petraccone, C. Spink, J. O. Trent, N. C. Garbett, C. S. Mekmaysy, C. Giancola and J. B. Chaires, J. Am. Chem. Soc., 2011, 133, 20951-20961; (d) V. Singh, M. Azarkh, M. Drescher and J. S. Hartig, Chem. Commun., 2012, 48, 8258-8260; (e) R. Hansel, F. Lohr, L. Trantirek and V. Dotsch, J. Am. Chem. Soc., 2013, 135, 2816-2824.

6 A. Bugaut and P. Alberti, Biochimie, 2015, 113, 125-133.

7 (a) L. P. Bai, M. Hagihara, Z. H. Jiang and K. Nakatani, ChemBioChem, 2008, 9, 2583-2587; (b) K. Shinohara, Y. Sannohe, S. Kaieda, K. Tanaka, H. Osuga, H. Tahara, Y. Xu, T. Kawase, T. Bando and H. Sugiyama, J. Am. Chem. Soc., 2010, 132, 3778-3782; (c) A. Cummaro, I. Fotticchia, M. Franceschin, C. Giancola and L. Petraccone, Biochimie, 2011, 93, 1392-1400; (d) C. Q. Zhao, L. Wu, J. S. Ren, Y. Xu and X. G. Qu, J. Am. Chem. Soc., 2013, 135, 18786-18789; (e) L. N. Zhu, B. Wu and D. M. Kong, Nucleic Acids Res., 2013, 41, 4324-4335; ( $f$ ) K. Iida, G. Tsubouchi, T. Nakamura, S. Majima, H. Seimiya and K. Nagasawa, MedChemComm, 2013, 4, 260-264; (g) A. R. O. Cousins, D. Ritson, P. Sharma, M. F. G. Stevens, J. E. Moses and M. S. Searle, Chem. Commun., 2014, 50, 15202-15205; (h) X. X. Huang, L. N. Zhu, B. Wu, Y. F. Huo, N. N. Duan and D. M. Kong, Nucleic Acids Res., 2014, 42, 8719-8731; ( $)$ Q. Zhang, Y. C. Liu, D. M. Kong and D. S. Guo, Chem. - Eur. J., 2015, 21, 13253-13260; ( j) M. H. Hu, S. B. Chen, B. Wang, T. M. Ou, L.Q.Gu,J.H.TanandZ.S. Huang, NucleicAcidsRes., 2017,45, 1606-1618.

8 G. Pennarun, C. Granotier, L. R. Gauthier, D. Gomez, F. Hoffschir, E. Mandine, J. F. Riou, J. L. Mergny, P. Mailliet and F. D. Boussin, Oncogene, 2005, 24, 2917-2928.

9 C. Granotier, G. Pennarun, L. Riou, F. Hoffschir, L. R. Gauthier, A. De Cian, D. Gomez, E. Mandine, J. F. Riou, J. L. Mergny, P. Mailliet, B. Dutrillaux and F. D. Boussin, Nucleic Acids Res., 2005, 33, 4182-4190.

10 (a) A. Paul, A. K. Jain, S. K. Misra, B. Maji, K. Muniyappa and S. Bhattacharya, PLoS One, 2012, 7, e39467; (b) K. Iida, S. Majima, T. Nakamura, H. Seimiya and K. Nagasawa, Molecules, 2013, 18, 4328-4341; (c) C. Q. Zhou, J. W. Yang, C. Dong, Y. M. Wang, B. Sun, J. X. Chen, Y. S. Xu and W. H. Chen, Org. Biomol. Chem., 2016, 14, 191-197; (d) C. Q. Zhou, T. C. Liao, Z. Q. Li, J. Gonzalez-Garcia, M. Reynolds, M. Zou and R. Vilar, Chem. - Eur. J., 2017, 23, 47134722; (e) Z. Q. Li, T. C. Liao, C. Dong, J. W. Yang, X. J. Chen,

L. Liu, Y. Luo, Y. Y. Liang, W. H. Chen and C. Q. Zhou, Org. Biomol. Chem., 2017,15,10221-10229.

11 P. Murat, Y. Singh and E. Defrancq, Chem. Soc. Rev., 2011, 40, 5293-5307.

12 K. Iida, M. Tera, T. Hirokawa, K. Shin-ya and K. Nagasawa, Chem. Commun., 2009, 6481-6483.

13 S. M. Haider and S. Neidle, Biochem. Soc. Trans., 2009, 37, 583-588.

14 J. Audry, L. Maestroni, E. Delagoutte, T. Gauthier, T. M. Nakamura, Y. Gachet, C. Saintome, V. Geli and S. Coulon, EMBOJ., 2015, 34, 1942-1958.

15 (a) L. Safa, E. Delagoutte, I. Petruseva, P. Alberti, O. Lavrik, J. F. Riou and C. Saintome, Biochimie, 2014, 103, 80-88; (b) L. Safa, N. M. Gueddouda, F. Thiebaut, E. Delagoutte, I. Petruseva, O. Lavrik, O. Mendoza, A. Bourdoncle, P. Alberti, J. F. Riou and C. Saintome, J. Biol. Chem., 2016, 291, 21246-21256. 


\title{
Binding properties of mono- and dimeric pyridine dicarboxamide ligands to human telomeric higher-order G-quadruplex structures
}

\author{
C. Saintomé, P. Alberti, N. Guinot, P. Lejault, J. Chatain, P.Mailliet, J.-F. Riou and A. \\ Bugaut* \\ a "Structure and Instability of Genomes" laboratory, Sorbonne Universités, Muséum National d'Histoire \\ Naturelle, Inserm U1154, CNRS UMR 7196, 75005 Paris, France. b UPMC Paris 6 Université, 75005 Paris, \\ France.*Corresponding author: abugaut@mnhn.fr
}

\section{Table of contents}

Supplementary tables and figures..........................................................2

Table S1 Sequences of the oligonucleotides used in this study.

Table S2 Calculated and obtained experimental values of the ligand-to-G4 unit molar ratios

Table S3 UV-melting temperatures of the complexes formed between the oligonucleotides and the ligands.

Fig. S1 (A) FRET melting curves of F21T in the presence of (A) $1 \mu \mathrm{M}$ of 360A, (B) $0.5 \mu \mathrm{M}$ and (C) 1 $\mu \mathrm{M}$ of $(360 \mathrm{~A})_{2 \mathrm{~A}}$, without or with $3 \mu \mathrm{M}$ or $10 \mu \mathrm{M}$ of double-stranded competitor ds26.(B)Representative FRET melting curves of H69Q1 in the presence of $1.5 \mu \mathrm{M}$ of $(360 \mathrm{~A})_{2 \mathrm{~A}}$ without or with $10 \mu \mathrm{M}$ of double-stranded competitor ds26. (C) FRET melting temperatures of H69Q1,Q2,Q3 in presence of $1.5 \mu \mathrm{M}$ of (360A) $)_{2 \mathrm{~A}}$ without or with $10 \mu \mathrm{M}$ of ds26.

Fig. S2 Changes in the CD spectra and changes in the maximum CD value of H21, H45 and H69 upon addition of increasing amounts of (360A) $)_{2 \mathrm{~A}}$ in $10 \mathrm{mM}$ lithium cacodylate $\mathrm{pH}$ 7.2, $10 \mathrm{mM} \mathrm{KCl}, 90 \mathrm{mM}$ LiCl.

Fig. S3 Changes in the CD spectrum and changes in the maximum CD value of $\mathrm{H} 45$ upon addition of increasing amounts of $360 \mathrm{~A}$ and $(360 \mathrm{~A})_{2 \mathrm{~A}}$.

Fig. S4 Changes in the CD spectrum and changes in the maximum CD value of H93 upon addition of increasing amounts of $360 \mathrm{~A}$ and $(360 \mathrm{~A})_{2 \mathrm{~A}}$.

Fig. S5 Changes in the CD spectra and the maximum CD values of H45(TTA) $)_{3}$ and H69(TTA) $)_{3}$ in 10 $\mathrm{mM}$ lithium cacodylate $\mathrm{pH}$ 7.2, $100 \mathrm{mM} \mathrm{NaCl}$.

Fig. S6 (A) Percentage of inhibition of RPA binding to telomeric oligonucleotide substrate H45 in the presence of increasing concentrations of 360A or (360A) $)_{2 \mathrm{~A}}$ for 5 min prior to incubation with RPA for 20 min. (B) Percentage of displacement of RPA from the telomeric oligonucleotide substrate H45 upon addition of increasing amounts of 360A or (360A) $)_{2 \mathrm{~A}}$.

Fig. S7 (A) Percentage of inhibition of RPA binding to telomeric oligonucleotide substrate H69 with 5 $\mu \mathrm{M}$ of $360 \mathrm{~A}$ or $2.5 \mu \mathrm{M}$ of $(360 \mathrm{~A})_{2 \mathrm{~A}}$ for $5 \mathrm{~min}$ in the presence of double-stranded competitor ds26 prior to incubation with RPA for 20 min. (B) Percentage of displacement of RPA from the telomeric oligonucleotide substrate H69 (20 min incubation) in the presence of double-stranded competitor ds26 upon addition of $5 \mu \mathrm{M}$ of $360 \mathrm{~A}$ or $2.5(360 \mathrm{~A})_{2 \mathrm{~A}} \mu \mathrm{M}$ for $5 \mathrm{~min}$.

Fig. S8 (A) Percentage of inhibition of RPA binding to mutated telomeric oligonucleotide substrates H27mut, H51mut and H75mut in the presence of increasing concentrations of $360 \mathrm{~A}$ or $(360 \mathrm{~A})_{2 \mathrm{~A}}$ for 5 min prior to incubation with RPA for 20 min. (B) Percentage of displacement of RPA from the mutated telomeric oligonucleotide substrates H27mut, H51mut and H75mut upon addition of increasing amounts of $360 \mathrm{~A}$ or $(360 \mathrm{~A})_{2 \mathrm{~A}}$.

Materials and methods.

References.. 
Table S1: Sequences of the oligonucleotides used in this study

\begin{tabular}{|l|l|l|}
\hline $\begin{array}{c}\text { Sequence } \\
\text { name }\end{array}$ & $\begin{array}{c}\text { Number of } \\
\text { G4 unit }\end{array}$ & \multicolumn{1}{c|}{ Sequence (5' to 3') } \\
\hline H21 & 1 & $(\text { GGGTTA })_{3} G G G$ \\
\hline H45 & 2 & $(\text { GGGTTA })_{7} G G G$ \\
\hline H69 & 3 & $(\text { GGGTTA })_{11} G G G$ \\
\hline H93 & 4 & $(\text { GGGTTA })_{15} G G G$ \\
\hline H45(TTA $)_{3}$ & 2 & $(\text { GGGTTA })_{3} G G G(T T A)_{3}(G G G T T A)_{3} G G G$ \\
\hline H27mut & 0 & $\left.(\text { GGGTTA })_{3} G G G(T T A)_{3}\right]_{2}(\text { GGGTTA })_{3} G G G$ \\
\hline H51mut & 0 & TTAGGCTTACGGTTAGCGTTACGGTTA \\
\hline H75mut & 0 & $\begin{array}{l}\text { TTAGGCTTACGGTTAGCGTTACGGTTAGGCTTACGGTT } \\
\text { AGCGTTACGGTTA }\end{array}$ \\
\hline ds26 & 0 & $\begin{array}{l}\text { TTAGGCTTACGGTTAGCGTTACGGTTAGGCTTACGGTT } \\
\text { AGCGTTACGGTTAGGCTTACGGTTAGCGTTACGGTTA }\end{array}$ \\
\hline
\end{tabular}

Table S2: Calculated theoretical and obtained experimental values of the ligand to G4 unit molar ratios

\begin{tabular}{|c|c|c|c|c|c|c|}
\hline \multirow[t]{2}{*}{ Oligonucleotide } & \multirow{2}{*}{$\begin{array}{c}\text { Number of } \\
\text { G4 unit } \\
\left(n_{\mathrm{G} 4}\right)\end{array}$} & \multirow{2}{*}{$\begin{array}{c}\text { Number } \\
\text { of TTA } \\
\text { linker } \\
\left(\mathbf{n}_{\text {TTA }}\right)\end{array}$} & \multicolumn{2}{|r|}{ 360A } & \multicolumn{2}{|c|}{$(360 A)_{2 A}$} \\
\hline & & & Cal. $^{a}$ & Exp. & Cal. $^{a}$ & Exp. \\
\hline H21 & 1 & 0 & 2.00 & $1.87 \pm 0.13$ & 1.00 & $1.22 \pm 0.12$ \\
\hline $\mathrm{H} 45$ & 2 & 1 & 2.50 & $2.52 \pm 0.18$ & 1.50 & $1.55 \pm 0.08$ \\
\hline H69 & 3 & 2 & 2.67 & $2.74 \pm 0.08$ & 1.67 & $1.63 \pm 0.07$ \\
\hline H93 & 4 & 3 & 2.75 & $2.71 \pm 0.11^{\mathrm{b}}$ & 1.75 & $1.66 \pm 0.06^{b}$ \\
\hline
\end{tabular}

${ }^{a}$ Theoretical ligand/G4 unit molar ratio values were calculated as:

$\left(2 * n_{\mathrm{G} 4}+\mathrm{n}_{\mathrm{TTA}}\right) / \mathrm{n}_{\mathrm{G} 4}$, for $360 \mathrm{~A}$ and $\left(\mathrm{n}_{\mathrm{G} 4}+\mathrm{n}_{\mathrm{TTA}}\right) / \mathrm{nG} 4$, for $(360 \mathrm{~A})_{2 \mathrm{~A}}$

${ }^{\mathrm{b}}$ Experimental data for H93 are presented in Figure S4

Table S3: Apparent UV-melting temperatures $\left(\mathrm{Tm}_{\mathrm{APP}}\right)$ of the complexes formed between the oligonucleotides and the G4 ligands

\begin{tabular}{|c|c|c|c|}
\hline \multirow{2}{*}{$\begin{array}{l}\text { Oligonucleotide } \\
\text { (concentration) }\end{array}$} & $\operatorname{Tm}\left({ }^{\circ} \mathrm{C}\right)$ & $\mathrm{Tm}_{\mathrm{APP}}\left({ }^{\circ} \mathbf{C}\right)^{\mathbf{a}}$ & $\mathrm{Tm}_{\mathrm{APP}}\left({ }^{\circ} \mathbf{C}\right)^{\mathbf{a}}$ \\
\hline & DNA & DNA + 360A (2eq. G4) & DNA + (360A $)_{2 A}$ (1eq. G4) \\
\hline $\mathrm{H} 21(3 \mu \mathrm{M})$ & 60 & 64 & 70 \\
\hline H45 $(1.5 \mu \mathrm{M})$ & 53 & 70 & 73 \\
\hline H69 $(1 \mu \mathrm{M})$ & 47 & 70 & 74 \\
\hline
\end{tabular}

${ }^{\mathrm{a}}$ Values are given with an experimental error of $\pm 1^{\circ} \mathrm{C}$ 


\section{A}
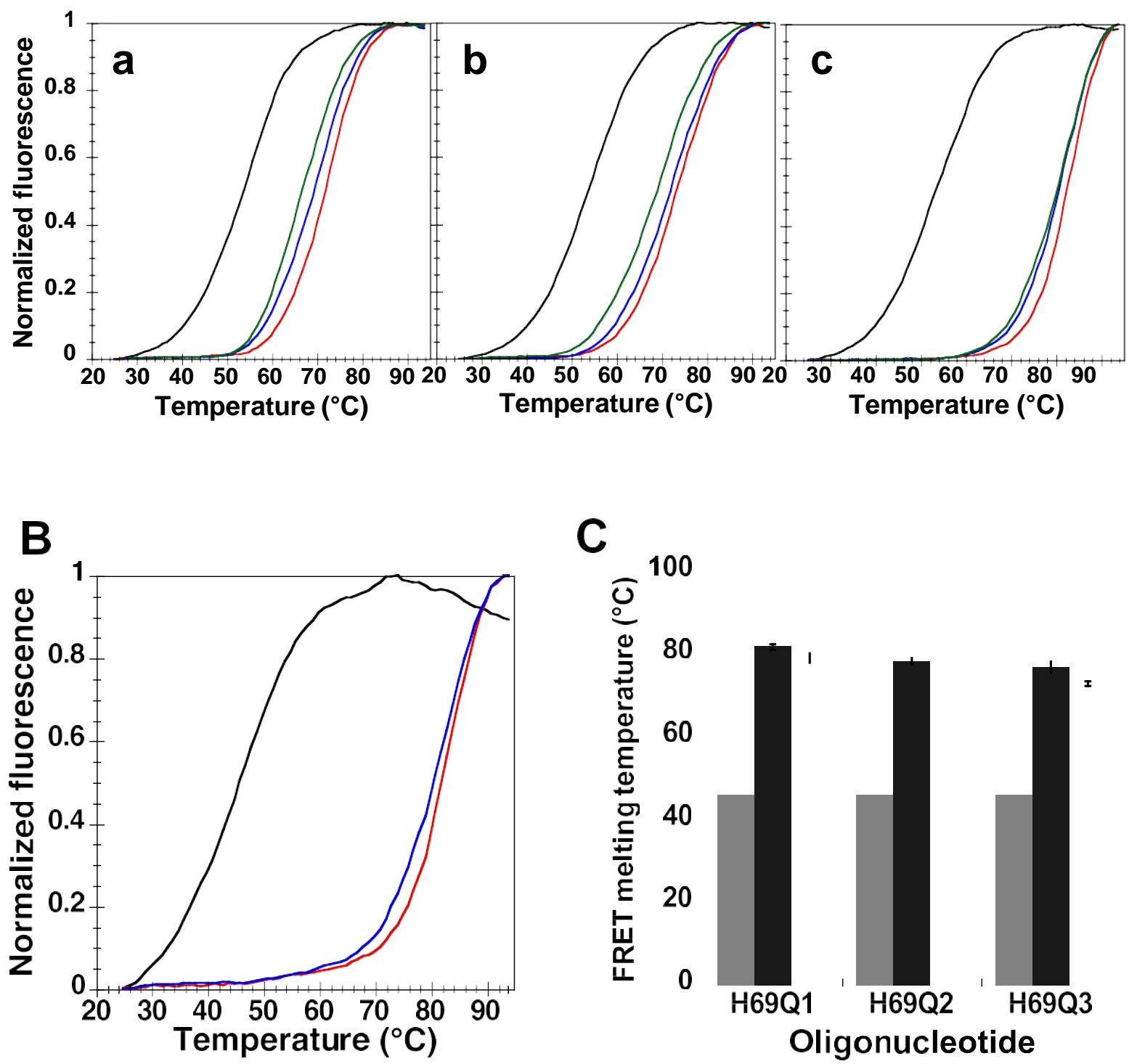

Fig. S1 (A) FRET melting curves of F21T (black) in the presence of (a) $1 \mu \mathrm{M}$ of 360A, (b) $0.5 \mu \mathrm{M}$ and (c) $1 \mu \mathrm{M}$ of (360A) $)_{2 \mathrm{~A}}$, without (red) or with $3 \mu \mathrm{M}$ (blue) or $10 \mu \mathrm{M}$ (green) of double-stranded competitor ds26. (B) Representative FRET melting curves of H69Q1 (black) in the presence of $1.5 \mu \mathrm{M}$ of (360A) $2 \mathrm{~A}$ without (red) or with (blue) $10 \mu \mathrm{M}$ of double-stranded competitor ds26. (C) FRET melting temperatures of H69Q1, H69Q2 and H69Q3 in the absence (grey bars) and in presence of $1.5 \mu \mathrm{M}$ of (360A) 2A $_{\text {A }}$ without (black bars) or with 10 $\mu \mathrm{M}$ (white bars) of ds26. Errors bars are standard deviation on triplicate. 
A

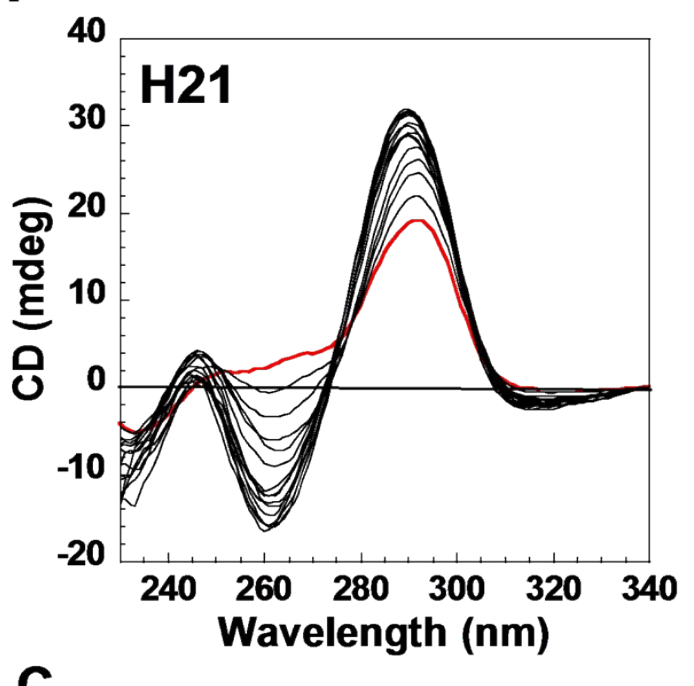

C

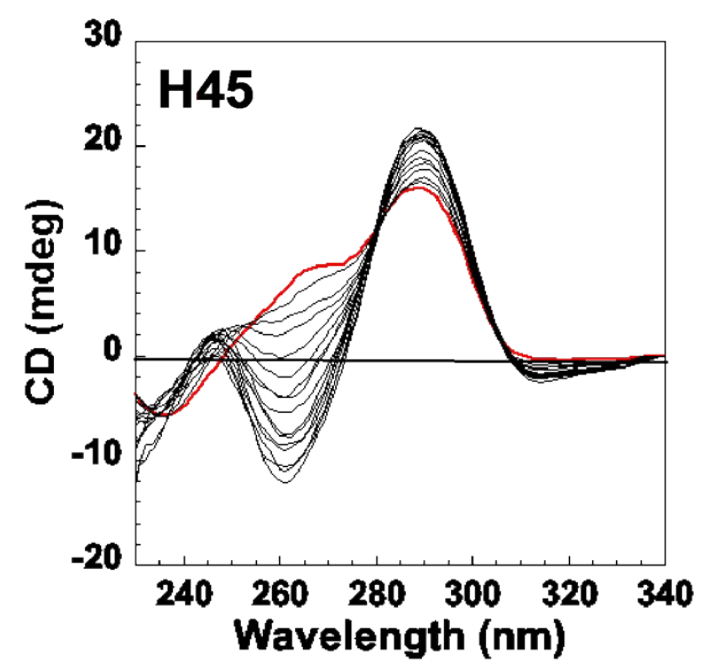

E

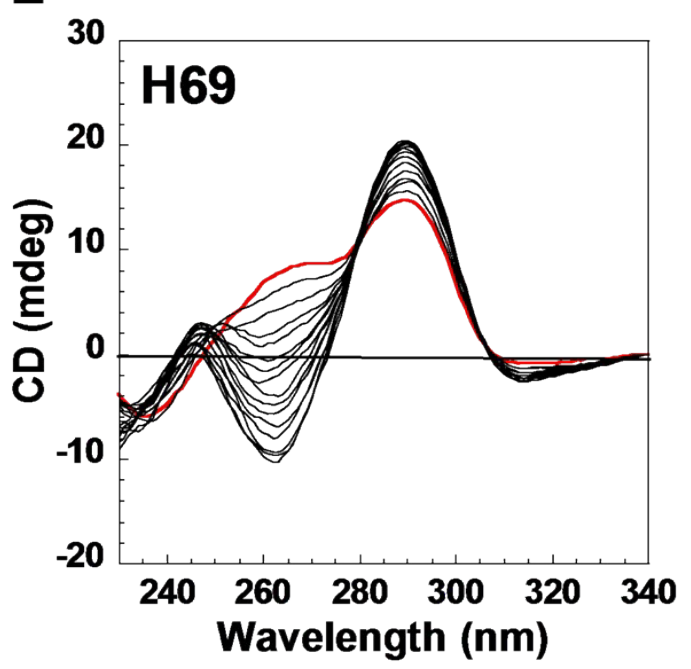

B

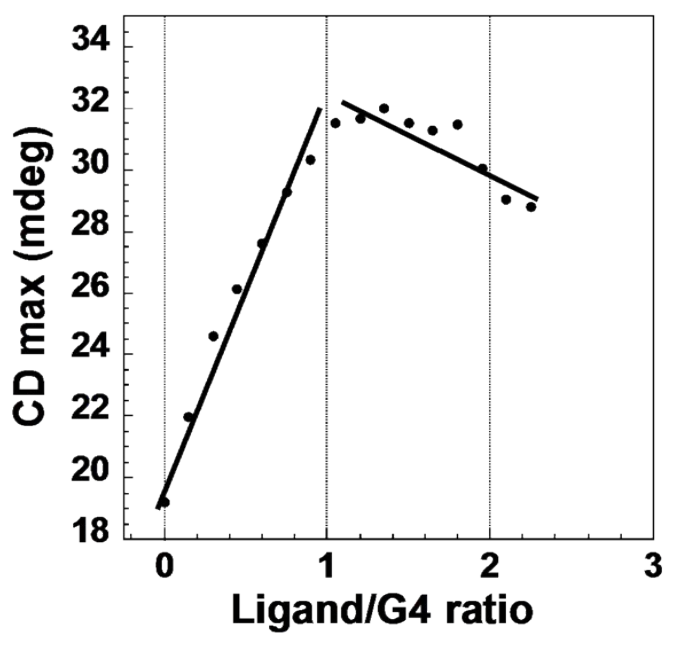

D

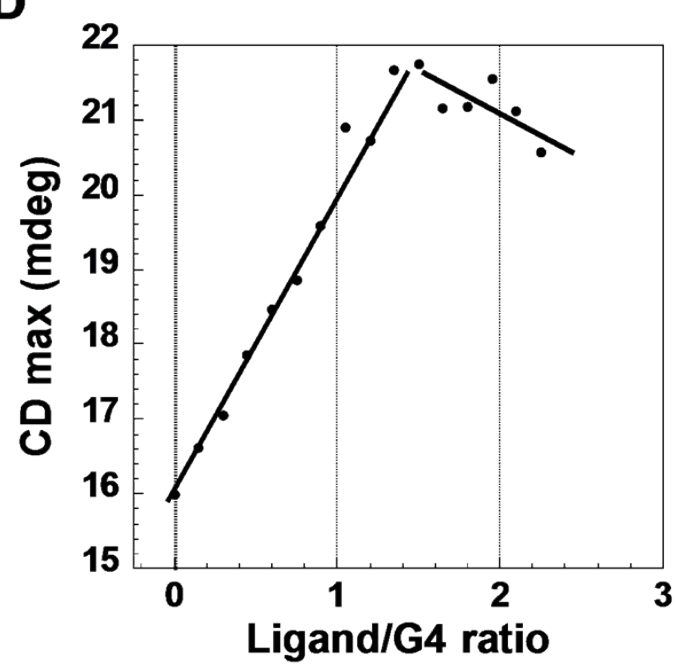

$\mathbf{F}$

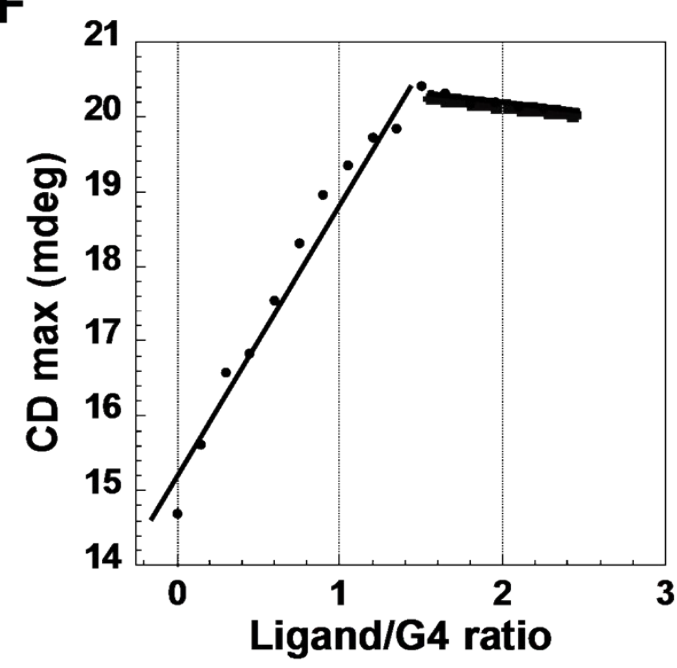

Fig. S2 (A,C and E) Changes in the CD spectra and (B, D and F) changes in the maximum CD values of H21 $(6 \mu \mathrm{M}), \mathrm{H} 45(3 \mu \mathrm{M})$ and $\mathrm{H} 69(2 \mu \mathrm{M})$ upon addition of increasing amounts of $(360 \mathrm{~A})_{2 \mathrm{~A}}$ in $10 \mathrm{mM}$ lithium cacodylate $\mathrm{pH}$ 7.2, $10 \mathrm{mM} \mathrm{KCl}, 90 \mathrm{mM} \mathrm{LiCl}$. The CD spectra in the absence of the ligand are in red. 

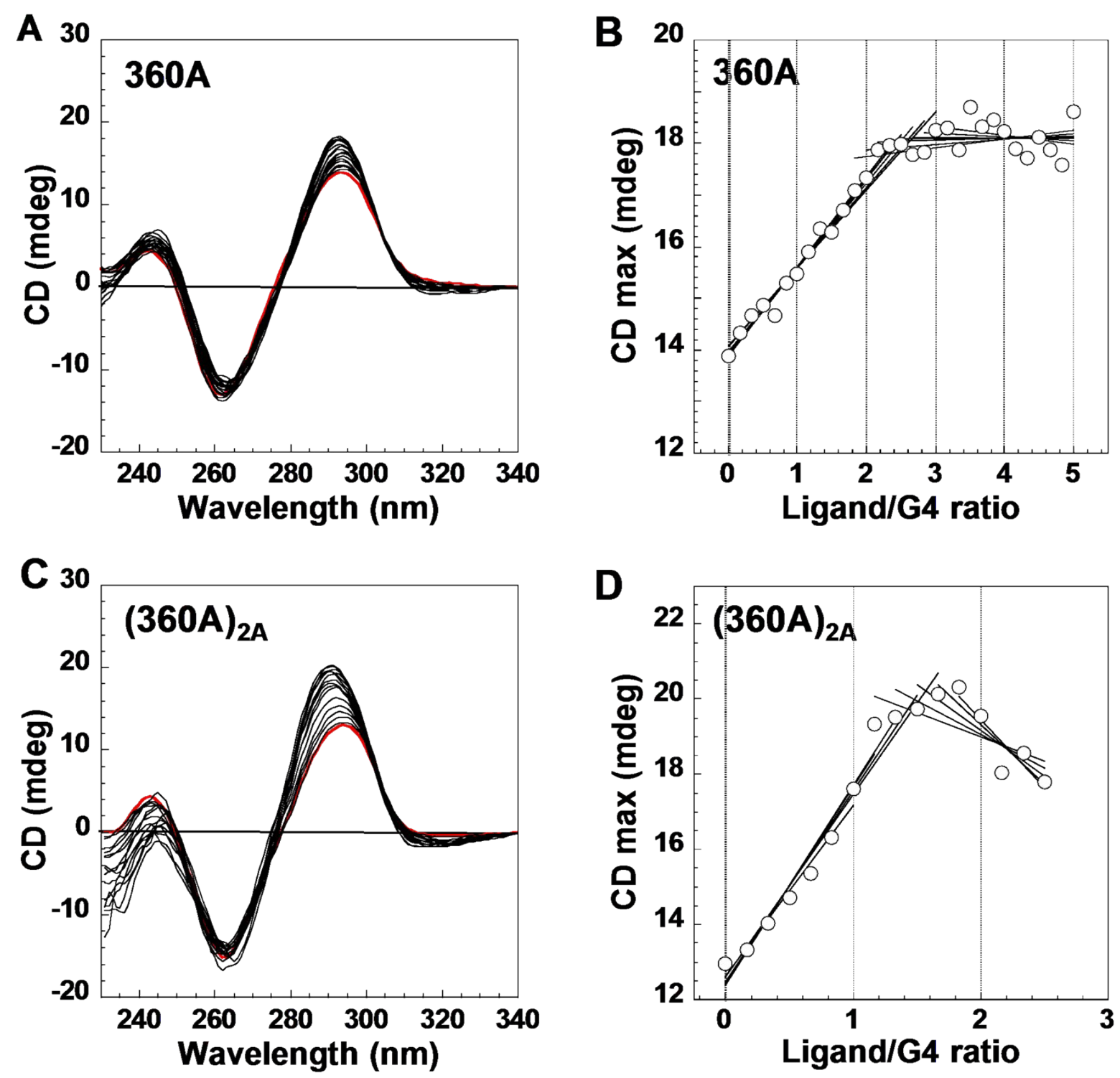

Fig. S3 (A and C) Changes in the CD spectrum and (B and D) changes in the maximum CD value of $\mathrm{H} 45$ (3 $\mu \mathrm{M}$ in $10 \mathrm{mM}$ lithium cacodylate $\mathrm{pH}$ 7.2, $100 \mathrm{mM} \mathrm{NaCl}$ ) upon addition of increasing amounts of 360A and (360A) $)_{2 \mathrm{~A}}$. The CD spectrum without ligand is in red. 

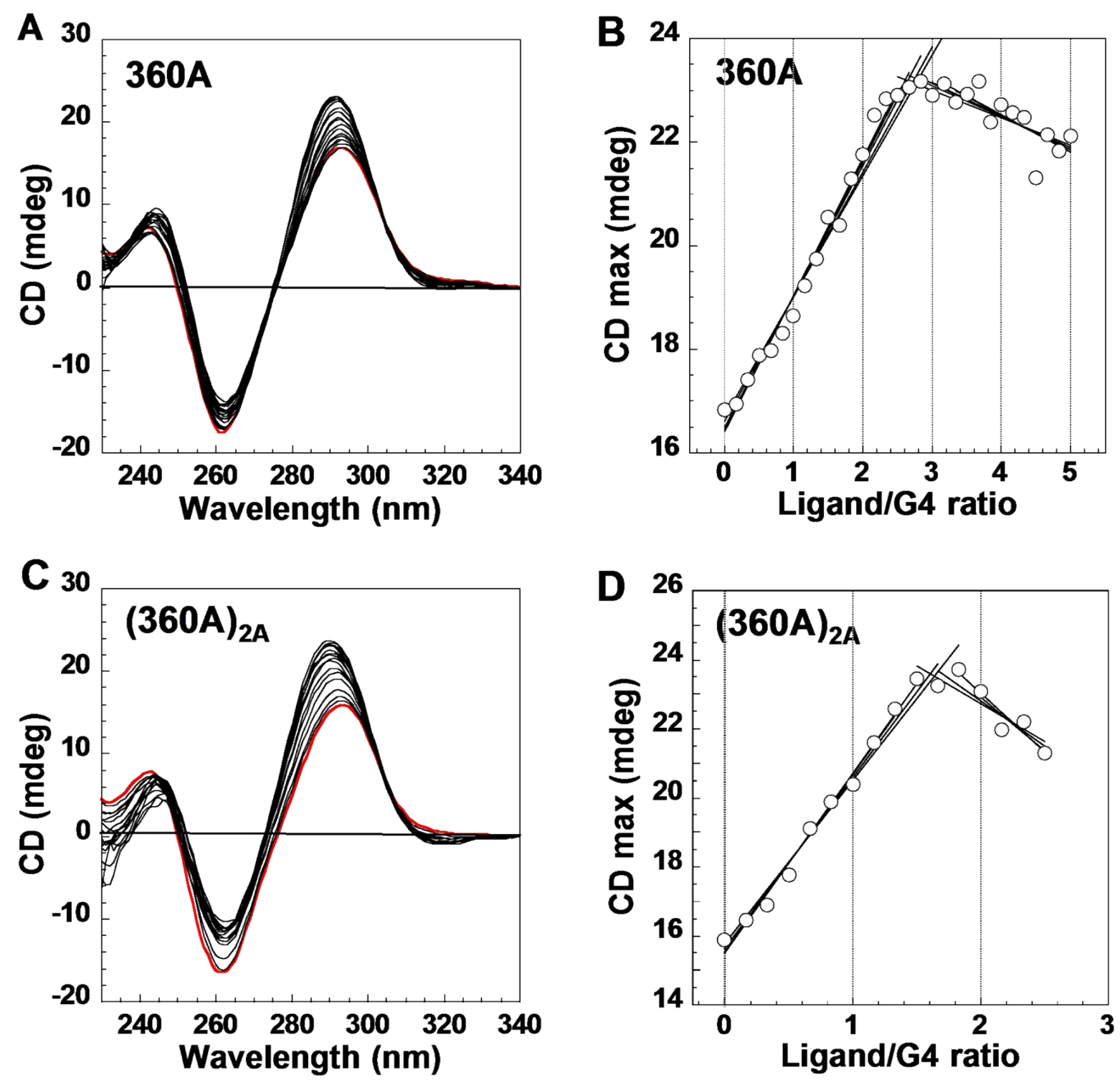

Fig. S4 (A and C) Changes in the CD spectrum and (B and D) changes in the maximum CD value of $\mathrm{H} 93(1.5 \mu \mathrm{M}$ in $10 \mathrm{mM}$ lithium cacodylate $\mathrm{pH} 7.2,100 \mathrm{mM} \mathrm{NaCl})$ upon addition of increasing amounts of $360 \mathrm{~A}$ and $(360 \mathrm{~A})_{2 \mathrm{~A}}$. The CD spectrum without ligand is in red. 

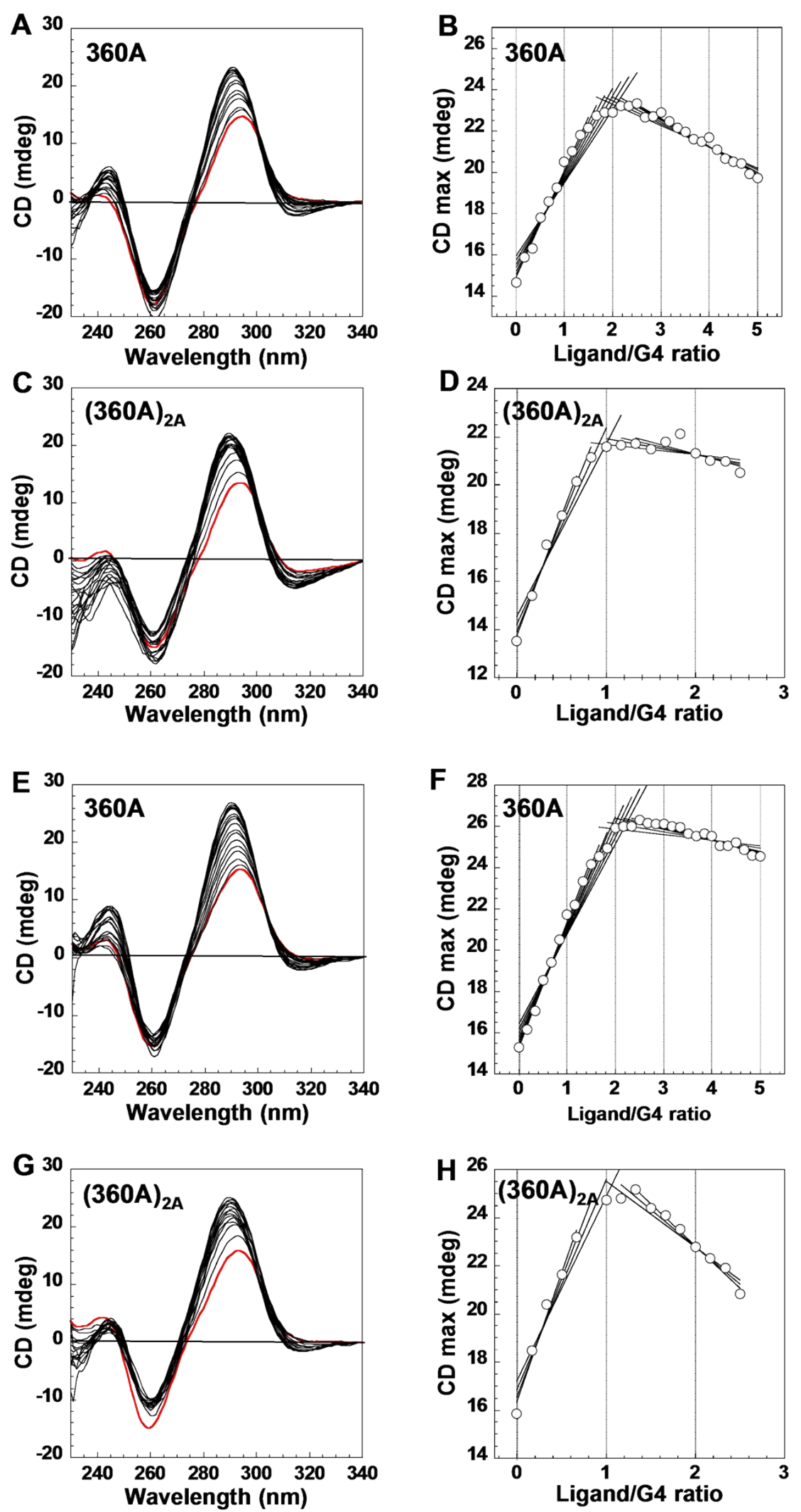

Fig. S5 Changes in the CD spectra and in the maximum CD values of (A-D) H45(TTA) $3(3$ $\mu \mathrm{M})$ and $(\mathrm{E}-\mathrm{H}) \mathrm{H} 69(\mathrm{TTA})_{3}(2 \mu \mathrm{M})$ upon addition of increasing amounts of $360 \mathrm{~A}$ and $(360 \mathrm{~A})_{2 \mathrm{~A}}$ in $10 \mathrm{mM}$ lithium cacodylate $\mathrm{pH} 7.2,100 \mathrm{mM} \mathrm{NaCl}$. The CD spectra in the absence of the ligands are in red. 

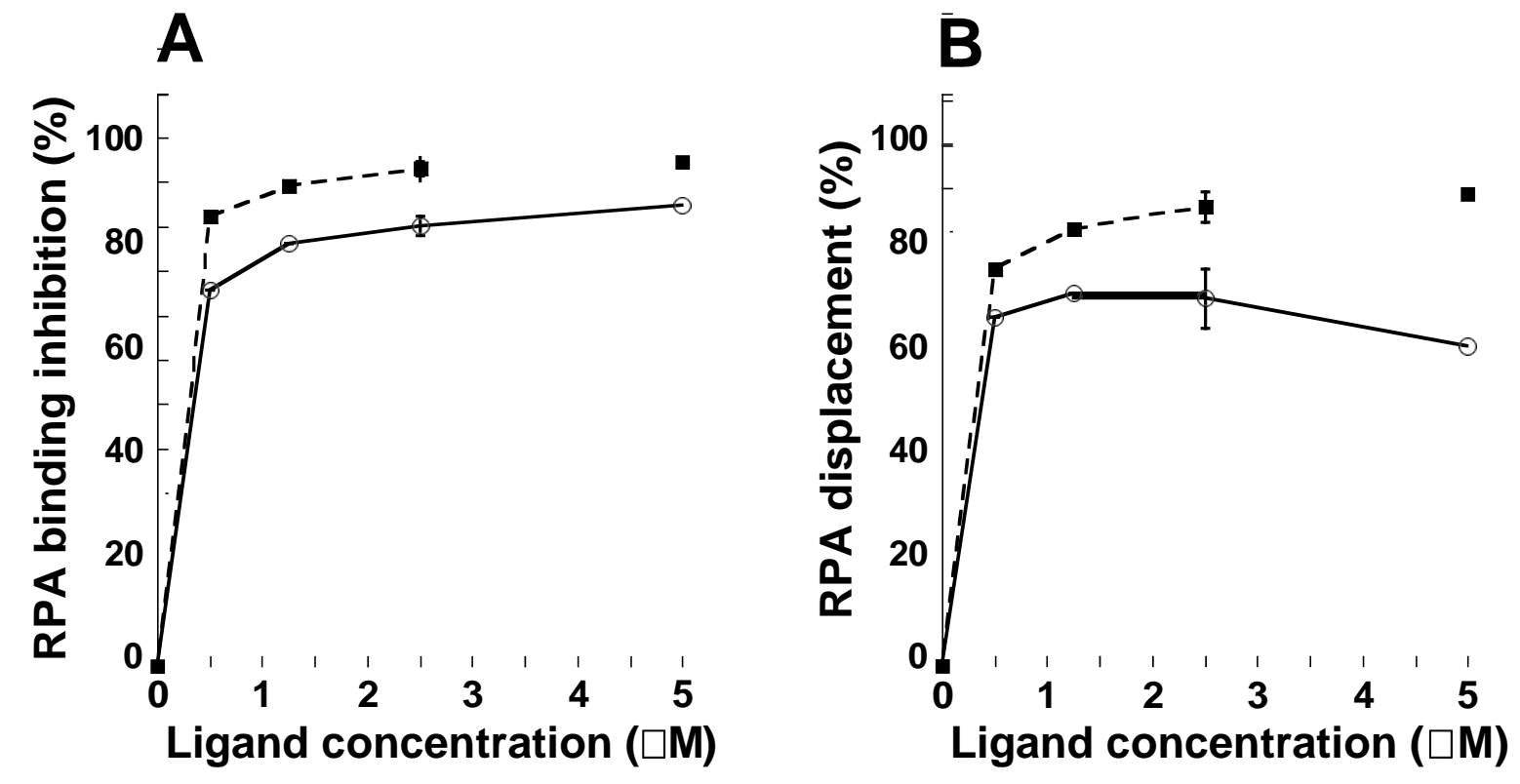

Fig. S6 (A) Percentage of inhibition of RPA binding to telomeric oligonucleotide substrate $\mathrm{H} 45$ in the presence of increasing concentrations of 360A (open circles) or (360A) $2 \mathrm{~A}$ (black squares) for 5 min prior to incubation with RPA for 20 min. (B) Percentage of displacement of RPA from the telomeric oligonucleotide substrate H45 (20 min incubation) upon addition

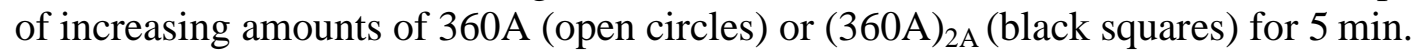


A

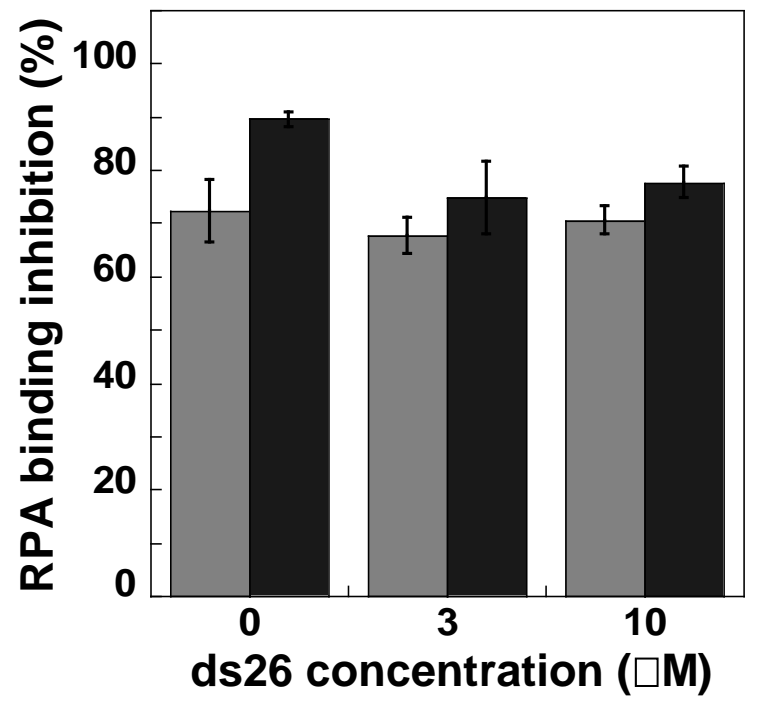

B

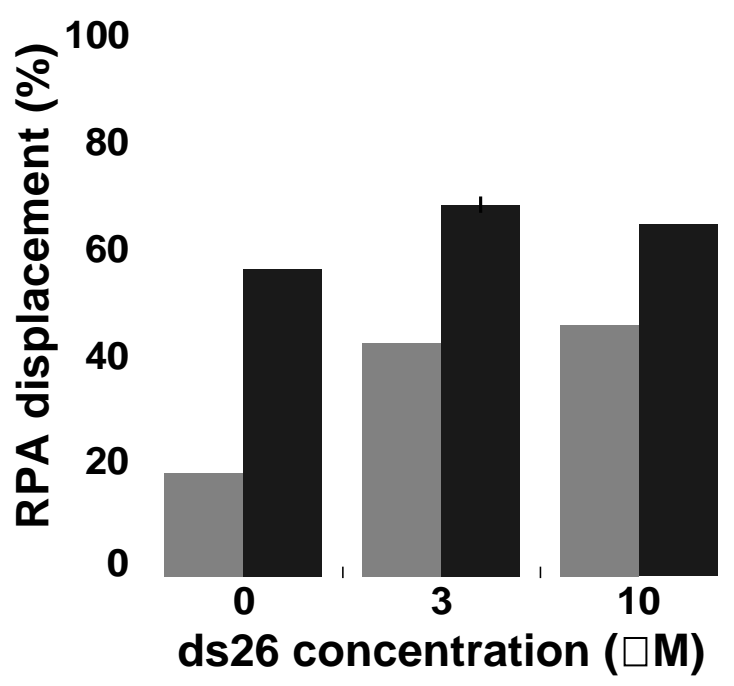

Fig. S7 (A) Percentage of inhibition of RPA binding to telomeric oligonucleotide substrate H69 with $5 \mu \mathrm{M}$ of $360 \mathrm{~A}$ (grey bars) or $2.5 \mu \mathrm{M}$ of (360A) 2A $_{\text {A }}$ (black bars) for $5 \mathrm{~min}$ in the presence of double-stranded competitor ds26 prior to incubation with RPA for $20 \mathrm{~min}$. (B) Percentage of displacement of RPA from the telomeric oligonucleotide substrate H69 (20 min incubation) in the presence of double-stranded competitor ds26 upon addition of $5 \mu \mathrm{M}$ of $360 \mathrm{~A}$ (grey bars) or $2.5(360 \mathrm{~A})_{2 \mathrm{~A}} \mu \mathrm{M}$ (black bars) for $5 \mathrm{~min}$. 


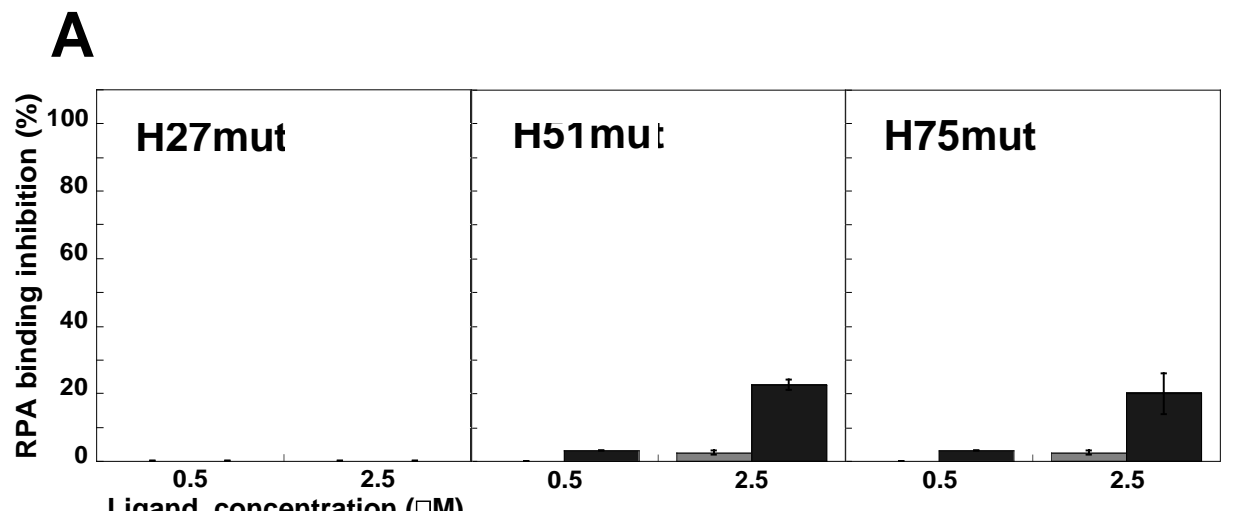

Ligand concentration ( $\square \mathrm{M})$

\section{B}

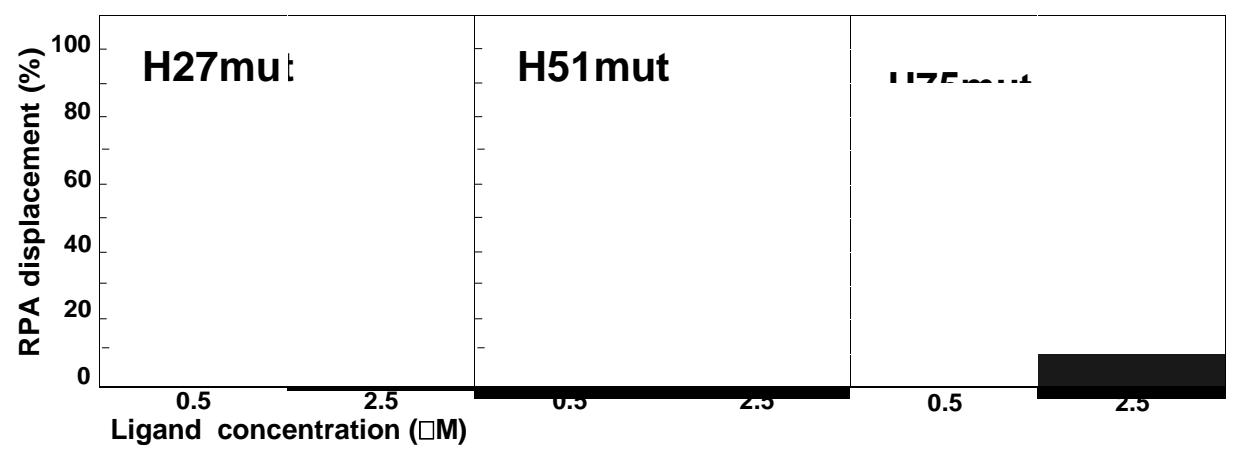

Fig. S8 (A) Percentage of inhibition of RPA binding to mutated telomeric oligonucleotide substrates H27mut, H51mut and H75mut in the presence of increasing concentrations of $360 \mathrm{~A}$ (grey bars) or (360A) $2 \mathrm{~A}$ (black bars) for 5 min prior to incubation with RPA for 20 min. (B) Percentage of displacement of RPA from the mutated telomeric oligonucleotide substrates H27mut, H51mut and H75mut (20 min incubation) upon addition of increasing amounts of $360 \mathrm{~A}$ (grey bars) or (360A) $)_{2 \mathrm{~A}}$ (black bars) for $5 \mathrm{~min}$. 


\section{Materials and methods}

\section{Oligonucleotides}

Reverse-phase HPLC-purified oligonucleotides were purchased from Eurogentec (Belgium). They were dissolved in bi-distilled water and stored at $-20^{\circ} \mathrm{C}$. Concentrations were determined by UV absorption in bi-distilled water, using the molar extinction coefficients provided by the manufacturer.

\section{Biochemical reagents}

BSA was purchased from Roche, $\gamma^{32} \mathrm{P}-\mathrm{ATP}$ was from PerkinElmer Life Sciences and T4 polynucleotide kinase was from New England Biolabs.

Recombinant hRPA was expressed in the E. coli BL21 (DE3) strain transformed with plasmid $\mathrm{pET}_{11 \mathrm{a}}$-hRPA that affords co-expression of RPA1, RPA2 and RPA3 subunits. The protein complex was purified as previously described. ${ }^{\mathrm{S} 1}$

\section{Chemical reagents and instrumentations}

Chemical reagents were purchased from Sigma-Aldrich and Fluka. Solvents were obtained from Carlo Erba. They were used without additional purification. Microwave heating was performed in a microwave synthesis reactor Monowave 300 (Anton Paar). Reverse-phase HPLC analysis and purification were performed on Agilent Technologies 1200 analytical and preparative apparatus piloted by an Agilent ChemStation program. In analytical HPLC standard conditions, compounds were analysed using a 25 min linear gradient of 0-to$100 \%$ water-acetonitrile- $0.1 \%$ TFA on an analytical (4.6 x $250 \mathrm{~mm}$ ) Kinetecs C18 EVO $5 \mu \mathrm{m}$ column (Phenomenex) at the flow rate of $1 \mathrm{~mL} \cdot \mathrm{mn}^{-1}$, with detection by UV-absorption at both 260 and $310 \mathrm{~nm}$. Reverse-phase preparative HPLC purifications were performed on a Waters column (Xbridge C18 $5 \mu \mathrm{m}, 19 \times 250 \mathrm{~mm}$ ) using a 25 min linear gradient of 0-100\% wateracetonitrile, containing $0.1 \%$ TFA, and monitored by UV detection at both 260 and $310 \mathrm{~nm}$. Mass spectrometry analysis by ESI Q-TOF was performed on a Q-Star instrument (Applied Biosystems) in the positive mode; analyses were performed in methanol or DMF. NMR spectra were recorded on a Bruker AVANCE 400 NMR spectrometer equipped with a ${ }^{1-} \mathrm{H}$ broad-band reverse gradient probehead. Stock solutions of the ligands $(5 \mathrm{mM})$ were prepared in DMSO and stored at $-20^{\circ} \mathrm{C}$.

\section{Chemical synthesis}

Synthesis of 360A molecule was carried out as previously described. ${ }^{\mathrm{S} 2}$

The dimer ligand $(360 \mathrm{~A})_{2 \mathrm{~A}}$ was prepared with a $32 \%$ overall yield following the three-step process depicted below. 


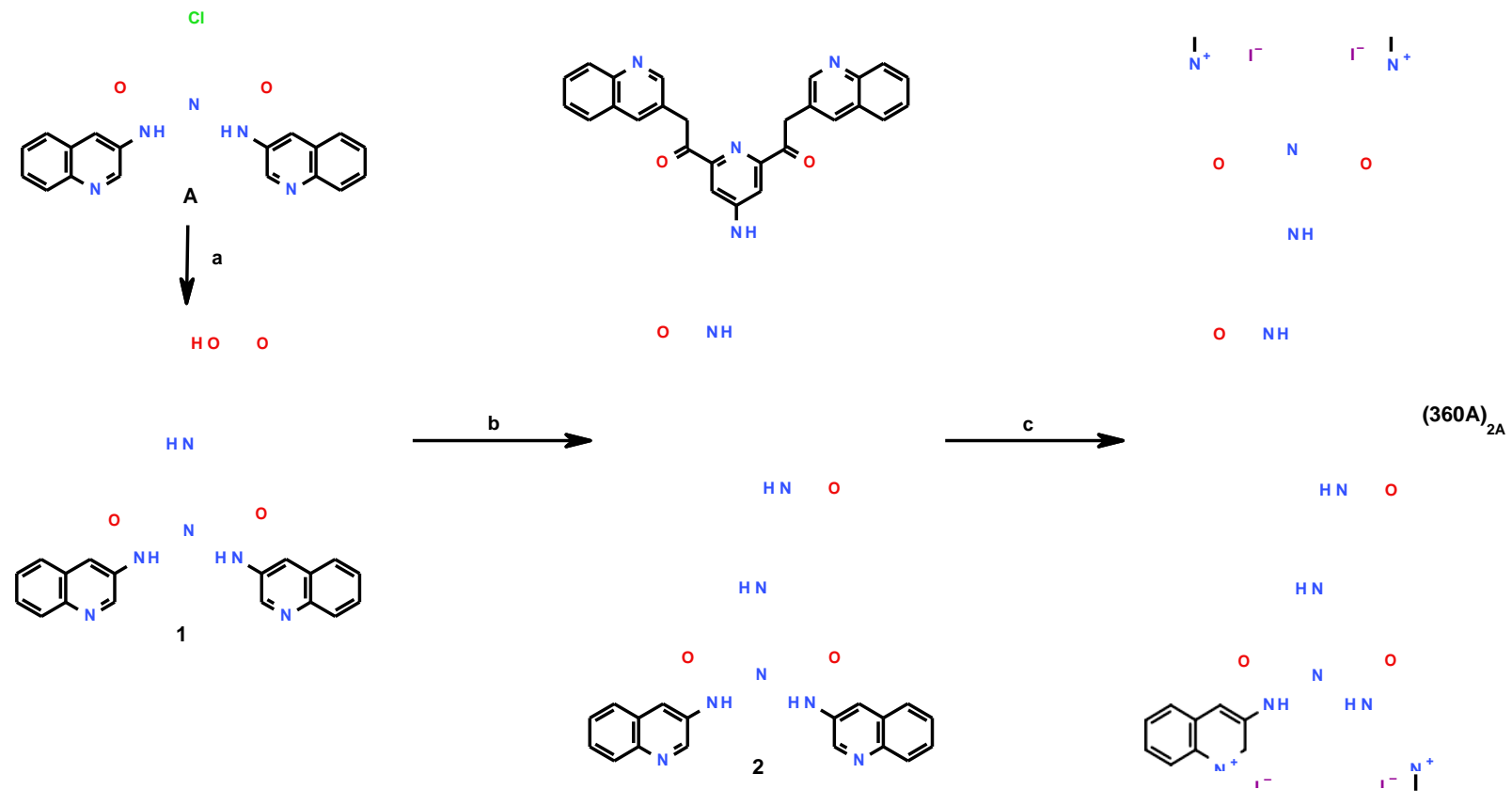

a) 4-aminobutyric acid / TEA / $2.5 \mathrm{~h}$ microwave heating in DMF at 140 . b) hexane-1,6-diamine / EDCl/ HOBt / 4 days at room temperature in DMF. c) excess methyl iodide / $4 \mathrm{~h}$ microwave heating in DMF at $110^{\circ}$.

\section{4-[2,6-bis(quinolin-3-yl)aminocarbonyl-pyridin-4-yl)aminobutyric acid (1):}

To a solution of $136 \mathrm{mg}$ (0.3 mmol) of N2,N6-(quinolin-3-yl)-4-chloro-pyridine-2,6dicarboxamide in DMF (5 mL) were added $34 \mathrm{mg}(0.33 \mathrm{mmol})$ of 4-aminobutyric acid and 42 $\mu \mathrm{L}(0.3 \mathrm{mmol})$ of triethylamine. After $2.5 \mathrm{~h}$ heating at $140^{\circ} \mathrm{C}$ in a microwave reactor and dilution with water (5 mL), the resulting colloidal mixture was centrifuged for $15 \mathrm{~min}$ at 4000 $\mathrm{rpm}$. The solid was washed by centrifugation with 50\% aqueous DMF (2 mL) and twice with water $(10 \mathrm{~mL})$, then dried $50^{\circ} \mathrm{C}$ under vacuum, yielding $72 \mathrm{mg}(46 \%)$ of almost pure (1), as an off-white powder (m.p. $>260^{\circ} \mathrm{C}$ ).

Rt (in standard analytical HPLC conditions) $=16.8 \mathrm{~min}$.

1H NMR (400MHz, DMSO) $\delta(\mathrm{ppm})=12.3-12.5$ (1H, bs), 11.4 (2H, s), $9.4(2 \mathrm{H}, \mathrm{s}), 8.95$ (2H, s), 8.05 (4H, m), 7.8 (2H, s), $7.65(2 \mathrm{H}, \mathrm{m}), 7.55$ (2, m), $5.6(\mathrm{~m}, 1 \mathrm{H}), 4.35$ (m, 2H), 2.4 (m, 2H), 1.65 (m, 2H).

SM (ESI-Q-TOF): [M+H] + = 521.45.

\section{1,6-\{4-[2,6-bis(quinolin-3-yl)aminocarbonyl-pyridin-4-yl]amino-butanoyl\}hexane-1,6- diamine (2) :}

$62.5 \mathrm{mg}(120 \mu \mathrm{mol})$ of (1) and $15 \mathrm{mg}(65 \mu \mathrm{mol})$ of hexane-1,6-diamine were dissolved in dry DMF (2 mL). $23 \mathrm{mg}(120 \mu \mathrm{mol})$ of 1-ethyl-3-(3-dimethylaminopropyl)carbodiimide (EDCI) and $3.4 \mathrm{mg}(25 \mu \mathrm{mol})$ of 1-hydroxybenzotriazole (HOBt) were then added. After 4 days stirring at room temperature the yellow solution was diluted with water $(2 \mathrm{~mL})$. The white colloidal precipitate formed was separated by centrifugation at $4000 \mathrm{pm}$ for $15 \mathrm{~min}$, washed with water and dried at $50^{\circ} \mathrm{C}$ under vacuum. The crude product, dissolved in DMF, was purified by reverse-phase preparative HPLC in the conditions previously described and yielded $57 \mathrm{mg}$ (85\%) of (2) as a white solid (m.p. $>260^{\circ} \mathrm{C}$ ).

Rt (in standard analytical HPLC conditions) $=19.5$ min .

SM (ESI-Q-TOF): [M+H] + = 1121.21.

1,6-\{4-[2,6-bis(1-methyl-quinolinio-3-yl)aminocarbonyl-pyridin-4-yl]aminobutanoyl\}hexane-1,6-diamine, tetra iodide $\left((360 \mathrm{~A})_{2 \mathrm{~A}}\right)$ : 
$56 \mathrm{mg}(50 \mu \mathrm{mol})$ of (2) and $250 \mu \mathrm{L}(567 \mathrm{mg}, 4 \mathrm{mmol})$ of methyl iodide were dissolved in DMF $(1.5 \mathrm{~mL})$ and heated at $110^{\circ} \mathrm{C}$ for $4 \mathrm{~h}$ in a microwave reactor. By cooling at room temperature, crystals separated that were filtered-off, washed successively with DMF ( 2 x 0.2 $\mathrm{mL})$, ethanol ( $2 \times 0.5 \mathrm{~mL})$ and diethyl ether $(2 \times 2 \mathrm{~mL})$ and dried, yielding $67 \mathrm{mg}(79 \%)$ of pure (360A) $)_{2 \mathrm{~A}}$, as bright yellow crystals.

Rt (in standard analytical HPLC conditions) $=18.7 \mathrm{~min}$.

SM (ESI-Q-TOF): [M+2H] 2+ = 589.60; $[\mathrm{M}+\mathrm{H}]+=1179.21$.

\section{Spectroscopic measurements}

Oligonucleotide samples were prepared in a $10 \mathrm{mM}$ cacodylic acid buffer at $\mathrm{pH} 7.2$ in bi-distilled water (adjusted with $\mathrm{LiOH}$ ), containing $100 \mathrm{mM} \mathrm{NaCl}$ or $10 \mathrm{mM} \mathrm{KCl}$ plus $90 \mathrm{mM}$ $\mathrm{LiCl}$, and placed in quartz cells (Hellma) with an optical pathway of $1 \mathrm{~cm}$.

CD spectra were recorded on a J-810 spectropolarimeter (Jasco) at $20^{\circ} \mathrm{C}$, after annealing of the oligonucleotide samples by heating at $95^{\circ} \mathrm{C}$ on a heat block, followed by a slow cool down to room temperature. Measurements were carried out in quartz cells (Hellma) with an optical pathway of $1 \mathrm{~cm}$. CD spectra were obtained by averaging three scans at a scanning rate of $500 \mathrm{~nm} . \mathrm{min}^{-1}$. They were baseline corrected by subtracting the spectrum of a water filled quartz cell and zero corrected at $340 \mathrm{~nm}$. Titration experiments were performed by incremental additions of $3 \mu \mathrm{L}$ of a $180 \mu \mathrm{M}$ ligand solution, prepared in a $1 \mathrm{X}$ ad hoc buffer from a $5 \mathrm{mM}$ stock solution in DMSO, in a $540 \mu \mathrm{L}$ oligonucleotide solution. CD signal amplitudes were corrected for the dilution factor resulting from ligand additions.

UV-melting profiles were recorded on an Uvikon XL spectrophotometer (Secomam) equipped with a circulating water bath (Julabo) and a dry airflow in the sample compartment. Samples were heated at $95^{\circ} \mathrm{C}$ for $2 \mathrm{~min}$, cooled down at $5^{\circ} \mathrm{C}$, and then heated back at $95^{\circ} \mathrm{C}$, at a rate of $0.2^{\circ} \mathrm{C} \cdot \mathrm{min}^{-1}$. UV absorbance was recorded at 245, 260, 273, 295 and $335 \mathrm{~nm}$ every 5 min. Temperature was measured with a glass sensor immersed into a water filled quartz cell. Melting temperature ( $\mathrm{Tm}$ ) was obtained as the maximum of the first derivative of the melting profile recorded at $273 \mathrm{~nm}$.

\section{FRET melting experiment}

FRET melting experiments were performed in 96-well plates with F21T (FAM$\mathrm{G}_{3}\left[\mathrm{~T}_{2} \mathrm{AG}_{3}\right]_{3}$-Tamra, with FAM: 6-carboxyfluorescein and Tamra: 6carboxytretramethylrhodamine) and three modified H69 oligonucleotides, doubly labelled with FAM and a TAMRA at different : in H69Q1, the fluorophores are placed at both sides of the first (5') G4 unit, in H69Q2, they are placed at both sides of the second G4 unit and in H69Q3, they are placed at both sides of the third (3') G4 unit. Fluorescence melting curves were recorded with a Mx300P real-time PCR instrument (Stratagene), using a total reaction volume of $25 \mu \mathrm{L}$, with $0.2 \mu \mathrm{M}$ of oligonucleotide in a $10 \mathrm{mM}$ cacodylic acid buffer at $\mathrm{pH} 7.2$ in bi-distilled water (adjusted with $\mathrm{LiOH}$ ) containing $100 \mathrm{mM} \mathrm{NaCl}$. After a first equilibration step at $25^{\circ} \mathrm{C}$ during $5 \mathrm{~min}$, a stepwise increase of $1^{\circ} \mathrm{C}$ for 70 cycles to reach $95^{\circ} \mathrm{C}$ was performed and measurements were made done after each cycle with excitation at $492 \mathrm{~nm}$ and detection at $516 \mathrm{~nm}$. The melting of the G-quadruplex was monitored alone or with the ligands $360 \mathrm{~A}$ or $(360)_{2 \mathrm{~A}}$, and in the absence or in the presence of double-stranded competitor ds26 (Table S1).

\section{RPA binding assays}

Oligonucleotides were labelled with $\gamma^{32} \mathrm{P}$-ATP using T4 polynucleotide kinase. They were separated from non-incorporated $\gamma^{32} \mathrm{P}-\mathrm{ATP}$ through Biospin 6 columns (Biorad) according to the manufacturer's protocol. Prior binding experiments, stock solutions of hRPA 
were diluted and pre-incubated $10 \mathrm{~min}$ at $4^{\circ} \mathrm{C}$ in a buffer containing $50 \mathrm{mM}$ Tris-HCl, $\mathrm{pH} 7.5$, $100 \mathrm{mM} \mathrm{KCl}, 1 \mathrm{mM}$ DTT, $10 \%$ glycerol, $0.2 \mathrm{mg} / \mathrm{mL}$ BSA and $0.1 \mathrm{mM}$ EDTA.

Binding experiments were carried out in $10 \mu \mathrm{l}$ samples prepared in a reaction buffer containing $50 \mathrm{mM}$ HEPES, pH 7.9, $0.1 \mathrm{mg} / \mathrm{mL}$ BSA, and $100 \mathrm{mM} \mathrm{NaCl}$ and $2 \%$ glycerol. For the first set of experiments, radiolabeled oligonucleotides $(2 \mathrm{nM})$ were first incubated for 5 min at room temperature $\left(\sim 20^{\circ} \mathrm{C}\right)$ with various amounts of $\mathrm{G} 4$ ligands $(0,1.25,2.5$ or $5 \mu \mathrm{M}$ final concentrations) before addition of RPA (100-200 nM final concentration), and further incubation for $20 \mathrm{~min}$ at room temperature. In the displacement conditions, radiolabeled oligonucleotide substrates were first incubated with RPA for $20 \mathrm{~min}$ at room temperature prior to addition of the G4 ligands, and further incubation for 5 min. For experiments in the presence of double-stranded competitor ds26 (Table S1), the competitor was added at the same time as the radiolabeled oligonucleotide substrate.

Samples were then loaded on native $1 \%$ agarose gels prepared with $0.5 \mathrm{X}$ TBE buffer. Electrophoresis was performed in 0.5X TBE running buffer for $90 \mathrm{~min}$ at $5 \mathrm{~V} / \mathrm{cm}$ at room temperature in. Gel was then dried and exposed to a storage phosphor screen that was scanned with Typhoon ${ }^{\mathrm{TM}}$ FLA 95000 biomolecular imager (GE Healthcare). Band intensities (I) were quantified using ImageQuant 5.2. For each G4 ligand concentration, the fraction (F) of radiolabeled oligonucleotide substrate bound to RPA was calculated as $I_{\text {oligo bound }} /\left(I_{\text {oligo bound }}+\right.$ $\left.I_{\text {oligo free}}\right)$ and the RPA binding inhibition or displacement as $(F 0-F C) / F c$, where $F 0$ is the fraction of oligonucleotide bound in the absence of the ligand and $F_{C}$ the fraction bound in the presence of the ligand at the indicated concentration. Experiments were performed at least twice, with error bars representing the standard error on the mean.

\section{References}

S1 J. Audry, L. Maestroni, E. Delagoutte, T. Gauthier, T.M. Nakamura, Y. Gachet, C. Saintome, V. Geli, and S. Coulon, EMBO J., 2015, 34, 1942-1958.

S2 A. Hittinger, T. Caulfield, P. Mailliet, H. Bouchard, E. Mandine, J. L. Mergny, L. Guittat, J. F. Riou, D. Gomez, C. Belmokhtar, WO2004/072027. 